\title{
Factors Affecting Innovative Activities of SMEs in Slovak Regions
}

\author{
Katarina Havierniková ${ }^{1,{ }^{*}}$ and Marcel Kordoš ${ }^{1}$ \\ ${ }^{1}$ Alexander Dubček University in Trenčín, Študentská 2, 91150 Trenčín, Slovak Republic
}

\begin{abstract}
Innovations and innovation policies and strategies implementations are one of the most important aspects of current regional economics and business development issues. It is the key not only to creating more jobs, building a greener society and improving quality of life, but also to maintaining companies' competitiveness on regional markets and states'/economies' competitiveness enhancement within the international economics system. The goal of this paper is oriented on Slovak SMEs that carrying out their activities in eight administration regions and have knowledge or experience with cluster cooperation. Questionnaire research was executed in 8 Slovak regions where respondents were owners or managers of SMEs. For test of homogeneity of variance (homoscedasticity) the Levene's test was used. Innovations as individual stakeholders as well as whole cluster have an impact on clusters' growing development and success and ultimately contribute to the development of whole region.
\end{abstract}

Key words: SMEs, innovative activities, technology

\section{Introduction and Theoretical Background}

Small and medium-sized enterprises (SMEs) are considered to be the most important elements of national economies [1]. Cluster includes manufacturing companies, universities, scientific workplaces, organizations in the economy. For small and mediumsized businesses cluster offer a wide variety of benefits and make an environment be suitable for innovation and knowledge creation [2]. For this reason, regions with strong clusters and SMEs are considered to be innovation leaders. Globalization further deepens on these trends. Despite this fact, the level of awareness about benefits of cluster cooperation is still low. Some organizations, such as SMEs are not able to cope with difficulties or, on the contrary, or to use the benefits globalization brings to world markets. The process of globalization requires the adoption of highly flexible innovative solutions, which, in particular, are often not able to be implemented by SMEs [3, 4].

Innovation provides real benefits for us as citizens, consumers, and workers. It speeds up and improves the way we conceive, develop, produce and access new products, industrial processes and services [5]. It is the key not only to creating more jobs, building a greener society and improving our quality of life, but also to maintaining our competitiveness on global market [6]. Innovation policy is about helping companies to

\footnotetext{
* Corresponding author: katarina.haviernikova@tnuni.sk
} 
perform better and contributing to wider social objectives such as growth, jobs and sustainability [7].

Technology offers opportunities to business organizations to increase their profits and growth through the introduction of new and improved goods and services and through changes to their production processes. Technology also helps firms to restructure their global and regional patterns of production through investment in low cost locations or by sub-contracting to cheaper suppliers [8]. However, technology can also pose threats and challenges for firms particularly if they allow themselves to fall behind their competitors. Technological advance, because it involves change in products or production processes, is a risky business particularly for firms being not able to manage change very well $[9,27]$.

The rapid internationalization of technology means that firms need to monitor both their domestic and their foreign technological environments. For many industries, technology is of the utmost importance and can determine whether firms prosper or fall by the wayside [10]. That also applies not only to states but also to particular regions. Only economy with strong economic regions as an active member of international division of labor, producing high-tech products based on innovations is able to achieve sustainable economic growth $[11,28]$. Failing to do so, economy will be caught in the world economy periphery having no sources to secure economic development for sufficient quality of life. Thus issues such as innovation and technology in international and regional business environment, technological change and innovation by means of clusters and spillovers as the globalization engines and the role of innovations in regional economy are the crucial issues to achieve regional competitiveness enhancement $[12,13]$.

Technology has become internationalized. Thus, transnational companies take opportunities offered by the international environment to develop global research strategies, carrying out research and development both at home and abroad. Technology is a doubleedged sword for business offering many opportunities but also challenges [14]. On one hand, it opens up a variety of opportunities for business in terms of new products, processes, and markets [15]. On the other hand, it lets firms more open to a range of competitive threats such as takeover, increased competition and even to the theft of their technologies.

Joseph Schumpeter set technological change, specifically innovation - the creation and diffusion of new ways of doing things - at the very nears of the processes of economic growth and development [16]. Technological change is a fundamental force in shaping the patterns of transformation of the economy [17]. Therefore, it is one of the most important processes underlying the globalization of economic activity. Technological change, therefore, is a socially and institutionally embedded process. The ways in which technologies are used - even their very creation - are conditioned by their social and their economic context $[18,29]$. Nowadays this means primarily the values and motivations of capitalist business enterprises, operating within an intensely competitive system. Choices and uses of technologies are influenced by the drive for profit, capital accumulation and investment, increased market share and so on. Secondly, technology should be seen as, essentially, an enabling or a facilitating agent - asserting new structures, new organizational and geographical arrangements of economic activities, new products and new processes $[19,20,21]$. On the other hand, in a highly competitive environment, once a particular technology is in use by one firm, then its adoption by others may become virtually essential to ensure competitive survival.

The idea underlying the notion of national innovation systems is that the specific combination of social, cultural, political, legal, educational and economic institutions and practices varies systematically among national contexts $[22,30]$. Such nationally differentiated characteristics help to influence the kind of technology system that develops there together with its subsequent development trajectory. 
National and regional systems of innovation, in fact, consist of aggregations of localized knowledge clusters, sometimes termed technology districts or technopoles [23, 30]. Many of them are associated with major metropolitan areas, although some have developed outside the metropolitan sphere in rather less urbanized areas. Most of them are the outcome of historical process of cumulative, path-dependent growth processes although some are the deliberate creations of national technology policy. These technological agglomerations form one of the most significant features of current global economy [24, 31].

Technological change within the innovation processes are the main factors of current global economy development $[25,32]$. In this paper we focus only on those aspects of technological change that specifically influence the economic activities of SMEs in Slovak regions. We will try to identify some of those features of technological change that are most important in the regionalization of economic activity. Technological change is the dynamic core of economic growth and development; it is fundamental to the evolution of a global economic system. We focus on the geography of innovation, on the different scales national and local - at which innovation processes operate.

\section{Goal and Research Methodology}

The focus of this paper is oriented on Slovak SMEs that carry out their activities in eight administration regions and have knowledge or experience with cluster cooperation. Within the frame of the project VEGA 1/0953/16 "The evaluation of clusters' impact measurement on regional development of the Slovak Republic", several questionnaire surveys were realized in years 2016-2017. One part of them also covered the issues of SMEs' innovative activities. Innovation within individual stakeholders as well as whole cluster have an impact on clusters' growing development and success and ultimately contribute to the development of whole region. Into research that has connection with innovative activities were involved 320 SMEs of which 40 enterprises are from each region (BA - Bratislava, TT - Trnava, TN - Trenčín, ZA - Žilina, NR - Nitra, BB - Banská Bystrica, PO - Prešov, KE - Košice). Respondents were owners or managers of SMEs. SMEs operate in one of the following economic sectors: Industry, Agriculture, Energy, Tourism. Slovak clusters also operate in these economic sectors. Table 1 presents the main characteristics of respondents. The biggest category size of respondents in each region except Žilina region was presented by category of medium sized enterprises (50-249 employees). The most respondents according to economic sectors belonged to economic sector of Industry $(47.19 \%)$, the least were in the category of Energy $(5.00 \%)$. Within the category of medium sized enterprises $(50-249$ employees), the most respondents also belong to SMEs that carry out their activities in Industry sector (29.69\%), at least in sector of Energy (1.25\%). Within the category of small enterprises (10-49 employees), it was the same situation (Industry $-11.25 \%$, Energy $1.25 \%$ ). The different composition of respondents by economic sector we can see in the last category - micro enterprises (with 0-9 employees), where the most respondents belonged to sector of Agriculture (10.94\%) and the least, again to sector of Energy (2.50\%). 
Table 1. Main characteristics of the respondents (\%)

\begin{tabular}{|c|c|c|c|c|c|c|c|c|c|}
\hline \multirow{2}{*}{ Region } & \multicolumn{3}{|c|}{ Number of employees } & \multirow{2}{*}{ Total } & Economic & \multicolumn{3}{|c|}{ Number of employees } & Total \\
\cline { 2 - 7 } \cline { 8 - 11 } & $\mathbf{0 - 9}$ & $\mathbf{1 0 - 4 9}$ & $\mathbf{5 0 - 2 4 9}$ & & sector & $\mathbf{0 - 9}$ & $\mathbf{1 0 - 4 9}$ & $\mathbf{5 0 - 2 4 9}$ & \\
\hline BA & 3.75 & 3.44 & 5.31 & 12.50 & Industry & 6.25 & 11.25 & 29.69 & 47.19 \\
\hline TT & 4.06 & 3.13 & 5.31 & 12.50 & Agriculture & 10.94 & 10.00 & 7.50 & 28.44 \\
\hline TN & 3.75 & 3.44 & 5.31 & 12.50 & Energy & 2.50 & 1.25 & 1.25 & 5.00 \\
\hline ZA & 0.63 & 7.81 & 4.06 & 12.50 & Tourism & 6.25 & 8.44 & 4.69 & 19.38 \\
\hline BB & 4.06 & 3.44 & 5.00 & 12.50 & & & & & \\
\hline NR & 3.75 & 3.13 & 5.63 & 12.50 & & & & & \\
\hline PO & 3.75 & 1.88 & 6.88 & 12.50 & \multirow{2}{*}{ Total } & $\mathbf{2 5 . 9 4}$ & $\mathbf{3 0 . 9 4}$ & $\mathbf{4 3 . 1 3}$ & - \\
\hline KE & 2.19 & 4.69 & 5.63 & 12.50 & & & & & \\
\hline Total & $\mathbf{2 5 . 9 4}$ & $\mathbf{3 0 . 9 4}$ & $\mathbf{4 3 . 1 3}$ & - & & & & & \\
\hline
\end{tabular}

Source: Own research.

To meet the main goal of this paper two working hypotheses have been stated:

WH1 The assessment of factors that have impact on innovative activities of SMEs depends on size category of SMEs.

WH2 The assessment of reasons that lead SMEs toward cluster cooperation in the context of innovation activities depends on size category of SMEs.

To each working hypothesis, we set null and alternative hypothesis due to the statistical method being used.

For working hypothesis WH1 the set of eight factors that can have impact on innovative activities of SMEs were set: F1. Taxation, laws, regulations. F2. Low own innovation potential. F3. Customers' requirements. F4. Structure of the company. F5. Support from enterprise management. F6. Collaboration with suppliers. F7. Functioning work teams. F8. Cooperation in research and development, production and marketing.

Respondents could rate each factor by points from value 0 to 5 , while value 0 means that particular factor most embarrass the innovative activities of SMEs and value of 5 means that particular factor is most conducive to innovation activities of SMEs.

Using the analysis of variance for particular rated factors can be determined by whether their perception in the size categories is identical. For evaluation we used statistical methods (Levene's test, Lilliefors test and non-parametric multi-selective Kruskal-Wallis Test), the calculations were realized in statistical software Statistica [26].

For working hypotheses WH2 respondent could choose one from the six reasons that could mainly lead them towards cluster cooperation from the point of view of innovation. Particular reasons are: R1. Strategy of common business activities, R2. Management of common business activities, R3. Risk management, R4. Cost sharing, R5. New business impulses, R6. Optimizing the innovative idea. This W2 was evaluated by using Chi-square test.

\section{Results and discussion}

The necessary information for the analysis of variance in case of WH1 is shown in Table 2. The basic statistical characteristics are: the respondent evaluation average, the respondents' evaluation range measured by standard deviation. 
Table 2. The statistical characteristics of the evaluated factors

Source: Own research.

\begin{tabular}{|c|c|c|c|}
\hline Factor & $\boldsymbol{\mu}$ & $\boldsymbol{\sigma} \mathbf{2}$ & $\mathbf{S D}$ \\
\hline $\mathbf{F 1}$ & 1.80 & 0.94 & 0.97 \\
\hline F2 & 2.48 & 1.35 & 1.16 \\
\hline $\mathbf{F 3}$ & 3.70 & 1.67 & 1.29 \\
\hline F4 & 3.08 & 1.15 & 1.07 \\
\hline F5 & 3.53 & 1.77 & 1.33 \\
\hline F6 & 3.70 & 1.40 & 1.18 \\
\hline F7 & 3.89 & 1.06 & 1.03 \\
\hline F8 & 3.53 & 1.47 & 1.21 \\
\hline
\end{tabular}

The respondents in terms of size category of enterprise perceived the factor F7 being the most important factor that have influence on innovative activities of SMEs - Functioning work teams $(3.89 \pm 1.03$ points). The less important is the factor F1. Taxation, laws, regulations $(1,80 \pm 0,97$ points).

The percentage of respondents rating in total represents Table 3. As we can see, the highest rated value of 5 was obtained from respondents by two factors: F3 Customers' requirements $(28.40 \%)$ and F7 Functioning work teams $(28.40 \%)$. The least of respondents' responds to this value obtained the factor F1 Taxation, laws, regulations $(2.47 \%)$. It means that this factor is not so important for SMEs in case of obtaining benefits from cluster cooperation towards innovation activities.

Table 3. Respondents' rating of given factors (\%)

\begin{tabular}{|c|c|c|c|c|c|c|}
\hline Factor & $\mathbf{0}$ & $\mathbf{1}$ & $\mathbf{2}$ & $\mathbf{3}$ & $\mathbf{4}$ & $\mathbf{5}$ \\
\hline F1 & 2.47 & 44.44 & 29.63 & 19.75 & 1.23 & 2.47 \\
\hline F2 & 3.70 & 19.75 & 20.99 & 40.74 & 9.88 & 4.94 \\
\hline F3 & 3.70 & 6.17 & 4.94 & 16.05 & 40.74 & 28.40 \\
\hline F4 & 3.70 & 3.70 & 14.81 & 45.68 & 24.69 & 7.41 \\
\hline F5 & 3.70 & 6.17 & 9.88 & 22.22 & 30.86 & 27.16 \\
\hline F6 & 2.47 & 2.47 & 11.11 & 19.75 & 37.04 & 27.16 \\
\hline F7 & 1.23 & 2.47 & 4.94 & 17.28 & 45.68 & 28.40 \\
\hline F8 & 2.47 & 3.70 & 9.88 & 30.86 & 28.40 & 24.69 \\
\hline
\end{tabular}

Source: Own research.

For analysis of the variance, the parametric or nonparametric tests could be used. Parametric tests should be used when two following conditions are met: homogeneity of variance and normality.

For test of homogeneity of variance (homoscedasticity) the Levene's test was used, by which authors tested the null hypothesis that the population variances are equal. If the resulting p-value of Levene's test is less than significance level (0.05), the null hypothesis of equal variances is rejected and we can conclude that there is a difference among the variances in the population. Results of this test are in Table 4. 
Table 4. Levene's test of homoscedasticity

\begin{tabular}{|c|c|c|}
\hline Factor & $\mathbf{F}$ & $\mathbf{p}$ \\
\hline $\mathbf{F 1}$ & 3.78279 & 0.023793 \\
\hline F2 & 1.80602 & 0.165993 \\
\hline F3 & 10.95737 & 0.000025 \\
\hline F4 & 0.04446 & 0.956523 \\
\hline F5 & 2.98917 & 0.051750 \\
\hline F6 & 6.45246 & 0.001792 \\
\hline F7 & 0.08403 & 0.919421 \\
\hline F8 & 28.89852 & 0.000000 \\
\hline
\end{tabular}

Source: Own calculation, Significance level of $\mathrm{p}<0.05000$.

The results showed that null hypothesis about homoscedasticity is confirmed only for factors: F2. Low own innovation potential, F4. Structure of the company and F7. Functioning work teams.

To verify the normality of rated factors we used the Lilierfors' test. Results presents Table5 We test null hypothesis that the results of rated factors came from normal break-up values, against alternative hypothesis that results of rated factors came from basic set with different distribution. The results in Table 5, showed that at the significance level of 0.05 we rejected the null hypothesis of normality for each factor.

Table 5. Lilliefors test of normality

\begin{tabular}{|c|c|c|c|}
\hline Factor & Lilliefors & S-W & p \\
\hline F1 & $\mathrm{p}<0.01$ & 0.832198 & 0.000000 \\
\hline F2 & $\mathrm{p}<0.01$ & 0.914241 & 0.000000 \\
\hline F3 & $\mathrm{p}<0.01$ & 0.819456 & 0.000000 \\
\hline F4 & $\mathrm{p}<0.01$ & 0.884363 & 0.000000 \\
\hline F5 & $\mathrm{p}<0.01$ & 0.873099 & 0.000000 \\
\hline F6 & $\mathrm{p}<0.01$ & 0.860933 & 0.000000 \\
\hline F7 & $\mathrm{p}<0.01$ & 0.817839 & 0.000000 \\
\hline F8 & $\mathrm{p}<0.01$ & 0.886303 & 0.000000 \\
\hline
\end{tabular}

Source: Own research.

The results of Levene's and Lilliefors test are prerequisites to use a non-parametric Kruskal - Wallis test of variance. The results of variance analysis of particular rated factors done with this test are summarized in Table 6. 
Table 6. The results of Kruskal-Wallis Test

\begin{tabular}{|c|l|}
\hline Factor & Kruskal-Wallis Test \\
\hline F1 & $H(2, N=320)=10.81229 p=0.0045$ \\
\hline F2 & $H(2, N=320)=37.44249 p=0.0000$ \\
\hline F3 & $\mathrm{H}(2, \mathrm{~N}=320)=4.827061 \mathrm{p}=0.0895$ \\
\hline F4 & $\mathrm{H}(2, \mathrm{~N}=320)=4.595731 \mathrm{p}=0.1005$ \\
\hline F5 & $\mathrm{H}(2, \mathrm{~N}=320)=2.776082 \mathrm{p}=0.2496$ \\
\hline F6 & $\mathrm{H}(2, \mathrm{~N}=320)=3.592882 \mathrm{p}=0.1659$ \\
\hline F7 & $\mathrm{H}(2, \mathrm{~N}=320)=2.366810 \mathrm{p}=0.3062$ \\
\hline F8 & $H(2, N=320)=6.573793 p=0.0374$ \\
\hline
\end{tabular}

Source: Own research.

The grouping variable was the size category of SMEs. The authors tested the null hypothesis: The difference in mean values of rated factors among the size categories of SMEs is not statistically significant. The calculated $\mathrm{p}$-value of variance intensity analysis of rated factors is higher than 0.05 for factors: F3. Customers' requirements, F4. Structure of the company. F5. Support from enterprise management, F6. Collaboration with suppliers. F7. Functioning work teams. The null hypothesis is not rejected. For the rest of factors, the null hypothesis is rejected. It means that there are differences in respondents rating of particular factors. This has been confirmed by results of the multiple comparison performed by using the p-level. We can conclude, that at significance level of 0.05 the responses of respondents vary among the individual size categories of SMEs. The level of $p$-values was in each cases lower than 0.05 .

At the end we can conclude, that working hypothesis was confirmed only in several cases of rated factors: F1. Taxation, laws, regulations, F2. Low own innovation potential and F8. Cooperation in research and development, production and marketing. Within evaluation of this factors, the size category of SMEs plays the significant role.

For working hypothesis WH2, the basic information about respondents' decision is summarized in Table 7.

Table 7. Percentage statements of the respondents' answers (\%)

Source: Own research.

\begin{tabular}{|c|c|c|c|c|}
\hline \multirow{2}{*}{ Reason } & \multicolumn{3}{|c|}{ Number of employees } & \multirow{2}{*}{ Total } \\
\cline { 2 - 4 } & $\mathbf{0 - 9}$ & $\mathbf{1 0 - 4 9}$ & $\mathbf{5 0 - 2 4 9}$ & \\
\hline R1 & 10.63 & 10.94 & 19.69 & $\mathbf{4 1 . 2 5}$ \\
\hline R2 & 6.56 & 3.44 & 5.94 & $\mathbf{1 5 . 9 4}$ \\
\hline R3 & 0.31 & 2.50 & 1.56 & $\mathbf{4 . 3 8}$ \\
\hline R4 & 0.94 & 1.25 & 1.56 & $\mathbf{3 . 7 5}$ \\
\hline R5 & 5.00 & 10.00 & 10.00 & $\mathbf{2 5 . 0 0}$ \\
\hline R6 & 2.50 & 2.81 & 4.38 & $\mathbf{9 . 6 9}$ \\
\hline Total & $\mathbf{2 5 . 9 4}$ & $\mathbf{3 0 . 9 4}$ & $\mathbf{4 3 . 1 3}$ & $\mathbf{1 0 0 . 0 0}$ \\
\hline
\end{tabular}

The reason R1 has been marked by the most respondents $(41.25 \%)$. Strategy of common business activities as the most important from the point of view of innovation activities of SMEs in case of cluster cooperation. Reason R4. Cost sharing obtained only $3.75 \%$ of respondents' votes. 
If we evaluate the choice of reasons by the size category of enterprises, we can see a similar situation as was in the overall assessment, except in the category of micro enterprises, where the least respondents' votes was obtained by reason R3. Risk management.

To verify the working hypothesis WH2 we used statistical method Chi square test. We stated null hypothesis: Within the size categories of SMEs there is not difference in choosing the most important reason. The alternative hypothesis means opposite. The low level of $\mathrm{p}$ value $<0,05$ means that the $\mathrm{H} 0$ is rejected and we accept the alternative hypothesis H1. The result of Chi-square test (Pearson chi-sq: $16.5885, \mathrm{df}=10, \mathrm{p}=0.083999$ ) showed, that null hypothesis is not rejected. It means that evaluation of particular reasons doesn't depend on size category of SMEs. As the most important reasons for cluster cooperation in case of innovative activities are R1. Strategy of common business activities (41.25\%), R5. New business impulses (25.00\%) and R2. Management of common business activities $(15,94 \%)$.

\section{Conclusion}

The innovation capacity of SMEs is currently considered to be one of the conditions for the competitiveness of enterprises. In a changing business environment the innovation represent the tool for their managing. This paper presents the perception of selected factors that can have impact on innovation activities of SMEs: F1. Taxation, laws, regulations. F2. Low own innovation potential. F3. Customers' requirements. F4. Structure of the company. F5. Support from enterprise management. F6. Collaboration with suppliers. F7. Functioning work teams. F8. Cooperation in research and development, production and marketing. The results showed the differences in perception of these factors by SMEs. As the most important factor that has impact on innovation activities of SMEs was marked the F7. Functioning work teams. This factor was evaluated by 147 respondents by value 4 within the used scale. The least important factor according to SMEs is F1. Taxation, laws, regulations. This factor was marked in 143 cases by value 1 . The statistical significant differences in evaluation of SMEs for these two factors were also confirmed by using the Kruskal -Wallis test.

The innovation potential of SMEs is its internal characteristic and it is one of the basic elements for the development of this type of business entities. One way how to provide the transfer of innovation into SMEs is their connection into cluster cooperation, where subjects from main three areas are met: research and education, public administration, business environment. There are many reasons that lead the SMEs towards connection into cluster cooperation from the point of view of innovation. This paper provides evaluation results of six particular reasons by SMEs: R1. Strategy of common business activities, R2. Management of common business activities, R3. Risk management, R4. Cost sharing, R5. New business impulses, R6. Optimizing the innovative idea. As the most important reason was marked by $41,25 \%$ of respondents R1. Strategy of common business activities. By using Chi -square statistics we verified if there are differences in evaluation of selected reason in dependence of size category of business entity. Results showed, that evaluation of given reasons doesn't depend on the size category of SMEs.

The needs of innovation for the business environment of SMEs are the essence for their survival. The innovation activities contribute to their improving and gaining the competitive advantage. SMEs need to become aware that their interaction with the other regional subjects that represent the holder of innovation in form of cluster cooperation, gives them just what could move them forward and solve their everyday problems." 


\section{Acknowledgements}

This research was financially supported by the Slovak Ministry of Education's Scientific grant agency VEGA: "The evaluation of clusters' impact measurement on regional development of the Slovak Republic". Project registration number: [Reg. No.: 1/0953/16].

\section{References}

1. E. Krajňáková, A. Navikaite, V. Navickas, Paradigm Shift of Small and Medium-Sized Enterprises Competitive Advantage to Management of Customer Satisfaction. Inzinerine Ekonomika-Engineering Economics, 26(3), 327-332, (2015)

2. S. Brakman, H. Garretsen, Ch. Van Marrewijk, A. Van Witteloostuijn, Nations and firms in the global economy - an introduction to international economics and business. Cambridge University Press, (2006)

3. A. Malakauskaite, V. Navickas, Contribution of Clusters to the Competitiveness of Companies: Revelation and Evaluation. Inzinerine Ekonomika-Engineering Economics, 22(1), 50-57, (2011)

4. S. Vojtovic, The Impact of the Structural Funds on Competitiveness of Small and Medium-Sized Enterprises. Journal of Competitiveness, 8(4), 30-45, (2016)

5. L. Hamilton, P. Wepster, The International Business Environment. OUP Oxford, (2009)

6. P. Balaz, A. Hamara, Export Dependency of Slovakia on German's Economy. Politicka Ekonomie, 64(5), 573-590, (2016)

7. T. De Castro, P. Hnát, Czech FDI Performance: Between Global Value Chains and Domestic Reforms. Foreign Direct Investment in Central and Eastern Europe: PostCrisis Perspectives, 51-75, (2017)

8. P. Burda, J. Abrham, Z. Horváthová, Factors Influencing Online Civic Participation in Mid-Sized Czech Towns. Transformations in Business \& Economics, 16 (2B), 607618, (2017)

9. P. Drulák, R. Druláková, The richness of the liberal tradition in international relations: Karl Deutsch on political community and the European integration. International Relations, 28(3), 333-349, (2014)

10. L. Fojtíková, Trends in the revealed comparative advantages of the EU member states. Economic Annals-XXI, 161, 9-10, 7-11, (2016)

11. E. Ivanová, J. Masárová, Performance evaluation of the Visegrad Group countries. Economic Research-Ekonomska Istrazivanja, 31(1), 270-289, (2018)

12. L. Lipková, D. Braga, Measuring Commercialization Success of Innovations in the EU. Marketing and Management of Innovations, 4, 15-30, (2016)

13. M. Okręglicka, M. Mynarzová, R. Kaňa, Business process maturity in small and medium-sized enterprises [Dojrzałość procesów biznesowych w małych i średnich przedsiębiorstwach]”. Polish Journal of Management Studies, 12(1), 121-131, (2015)

14. S. Vojtovic, V. Navickas, V. Gruzauskas, Sustainable Business Development Process: The Case of the Food and Beverage Industry. Advancing Research in Entrepreneurship in the Global Context, 68, 225-239, (2016)

15. H. Machková, A. Sato, Analysis of Competitiveness of Belgian Sugar Industry. Listy Cukrovarnicke a Reparske, 133(12), 390-392, (2017)

16. J. H. Dunning, S. M. Lundan, Multinational Enterprises and the Global Economy. Edward Elgar Publishing, (2008) 
17. J. Mruškovičová, F. Dano, Optimizing the Number of Stops within the Logistic Routes Using the Mathematical Model. AD ALTA-Journal of Interdisciplinary Research, 7(1), 113-115, (2017)

18. J. Taušer, M. Arltová, P. Žamberský, Czech exports and german GDP: A closer look. Prague Economic Papers, 24(1), 17-37, (2015)

19. L. Mura, M. Orlíková, Social Entrepreneurship and Social Enterprises: The Case of Slovakia. Innovation Management Entrepreneurship and Corporate Sustainability, 495-505, (2016)

20. K. A. Reinert, An Introduction to International Economics. Cambridge University Press, (2012)

21. S. M. Obadi, M. Korček, Competitive Advantage of International Trade of the EU-28 and USA. Proceedings of 8th Annual International Scientific Conference: Competition, (2016)

22. M. Okręglicka, A. Lemańska-Majdzik, Cooperative with Competitive Environment as a Determinant of Competitive Position of Microenterprises in Poland. International Scientific Conference Knowledge for Market Use 2017: People in Economics Decisions, Behavior and Normative Models, (2017)

23. T. Sadílek, D. Zadražilová, Current Trends in German Sugar Industry. Listy Cukrovarnicke a Reparske, 132(12), 390-393, (2016)

24. J. Taušer, R. Čajka, Hedging techniques in commodity risk management. Agricultural Economics (Czech Republic), 60(4), 174-182, (2014)

25. F. Varadzin, Global Public Goods and Integration. Proceedings of the 3rd International Conference on European Integration, 1052-1059, (2016)

26. J. Betáková, R Zeman., J. Dvorský, T. Pavlenko, Analysis Of Selected Risks Arising From Human Activities. WIT Transactions on Ecology and the Environment, 199, 71$81,(2015)$

27. J. Sejkora, Poor Economics: A Radical Rethinking of the Way to Fight Global Poverty. Ekonomicky Casopis, 62(4), (2014)

28. S. Zemanová, R. Druláková, Making Global Goals Local Business in V4 Countries: V4 Entrepreneurs And The UN Global Compact. Globalization and its Socio-Economic Consequences, 2490-2497, (2016)

29. E. Haňuláková, F. Daňo, Circular Economy as a New Managerial Approach. AD ALTA-Journal of Interdisciplinary Research, 8(1), 95-98, (2018)

30. S. Žák, M. Kuchta, A. Miklošík, Monetising Content through Delivery of Advertisements: The Case of Ad Blockers. AD ALTA-Journal of Interdisciplinary Research, 8(1), 175-179, (2018)

31. J. Sejkora, Comparative advantage, economic structure and growth: The case of Senegal. South African Journal of Economic and Management Sciences, 20(1), 1-9, (2017)

32. K. Krajčo, Analysis of foreign direct investment in the industry of the Slovak Republic. Proceedings of the 2nd international conference on European integration 2014, (2014) 